\title{
金属アルコキシドからのチタン酸バリウム前駆体ゾルの合成
}

\author{
笠井紀宏・尾崎義治
}

(成蹊大学 工学部 工業化学科)

\section{Preparation of Barium Titanate Precursor Sol from Metal Alkoxides}

\author{
Toshihiro KASAI and Yoshiharu OZAKI \\ $\left(\begin{array}{l}\text { Department of Industrial Chemistry, Faculty of Engineering, Seikei University } \\ \text { 3-3-1, Kichijoji-kitamachi, Musashino-shi, Tokyo } 180\end{array}\right)$
}

\begin{abstract}
$\mathrm{A} \mathrm{BaTiO}_{3}$ precursor sol was prepared by controlled hydrolysis of $\mathrm{Ba}$-Ti mixed alkoxide solution in methoxyethanol. SrTiO , $\mathrm{BaZrO}_{3}$ and $\mathrm{SrZrO}_{3}$ precursor sols were also synthesized by the similar method. The hydrolysis condition of Ba-Ti system was as follows; a water-methoxyethanol mixed solution with less than $50 \mathrm{vol} \%$ of water was added to $3.6 \times 10^{-4} \mathrm{~mol} / \mathrm{ml}$ of alkoxide solution at room temperature. On adding over $50 \mathrm{vol} \%$ of water, partial gelation occurred, and heterogeneous sol or gel was formed. For Sr-Ti system, the hydrolysis condition was the same as that for Ba-Ti system. For Ba-Zr and $\mathrm{Sr}-\mathrm{Zr}$ system, the concentration of water which produces partial gelation was over 66 vol \%. The formed precursor sols transformed to one phase $\mathrm{BaTiO}_{3}, \mathrm{SrTiO}_{3}, \mathrm{BaZrO}_{3}$ or $\mathrm{SrZrO}_{3}$ by calcination. Furthermore, the result of EDX analysis for $\mathrm{SrTiO}_{3}$ showed that the obtained powder had homogeneous composition and its homogeneity was kept up to $1000^{\circ} \mathrm{C}$. Similar results may be expected for other systems.

[Received February 3, 1987 ; Accepted April 21, 1987]
\end{abstract}

Key-words : Metal alkoxide, $\mathrm{BaTiO}_{3}$ precursor sol, Sol, Ceramic processing, Powder preparation

\section{1. 緒言}

チタン酸バリウムはその誘電率がキュリー点近くの温 度で 1 万程度と, 他の材料と比較して極めて高く優れた 特性を示し, コンデンサー用材料等として注目されてい る. 従来, チタン酸バリウムは炭酸バリウムと二酸化于 タンを混合, 仮焼する固相反応で合成されてきたが1)，コ ンデンサーチップの小型化等に伴って粒子レベルで均一 な組成をもつチタン酸バリウム粉末が要求されてきた22. 特に Mazdiyasni は金属アルコキシドを加水分解する ことによって微粒のチタン酸バリウム粉末を合成し た . また，これまでよりも一層高度な分散状態を得る ため ${ }^{4)}$ ，セラミックス原料を粉末ではなくコロイド分散 系であるゾルとする，いわゆるゾルゲル法に関心が高 まってきている5).ゾルの調製は解こう剤を加えて凝集 体を解こうさせる解こう法や分子分散系をコロイド分散 系にまで凝集させる凝集法等がある ${ }^{6}$. バリウムとチ夕 ニウムの混合アルコキシドは, その加水分解反応を制御 することで凝集法によりある種のゾルを生成する．その ゾルはチタン酸バリウム粉末が分散したものではない が, それを熱処理することによってチタン酸バリウムが 生成するので, 本質的にはチタン酸バリウムゾルと等価 なものとして扱えると思われる. 本報告はチタン酸バリ ウム前駆体ゾルの合成実験に関するものである.

\section{2. 実験方法}

\section{1 試料の合成}

モレキュラーシーブを加えて 24 時間以上脱水させた 市販特級のアルコール $100 \mathrm{ml}$ に使用前にメタノールで 洗浄し, その後ベンゼンで洗浄して表面の被膜を除去し た市販特級の金属バリウム $5 \mathrm{~g}$ を加えてマグネチックス ターラでかくはんしながら反応させてバリウムアルコキ シドを合成した. 本実験で用いたアルコールはメタノー ル, エタノール, イソプロピルアルコールである.

アルコールがイソプロピルアルコールの場合について はバリウムとの反応を速めるために同じ操作を還流下で 行った.そこにモル比で $\mathrm{Ba}: \mathrm{Ti}$ が $1: 1$ となるように 市販 1 級のチタニウムテトライソプロポキシドを加え て, かくはんを更に 15 分間程度続けて十分に混合し, $\mathrm{Ba}-\mathrm{Ti}$ 混合アルコキシド溶液を調製した。調製した混 合アルコキシド溶液をロータリーエバポレーターを用い て, 過剩のアルコール溶媒をエバポレートした. そこに モレキュラーシーブを用いて 24 時間以上脱水させた市 販特級のメトキシエタノール $100 \mathrm{ml}$ を加え, 超音波振 動器を用いて溶解させ混合アルコキシドのメトキシエタ ノール溶液を得た。この溶液を加水分解するため, 純水 及び次の $(2) \sim(6)$ の 5 種類の水/メトキシエタノー ル混合溶液を用意した。

(1) 純水

（2）水/メトキシエタノール (80 vol \%) 


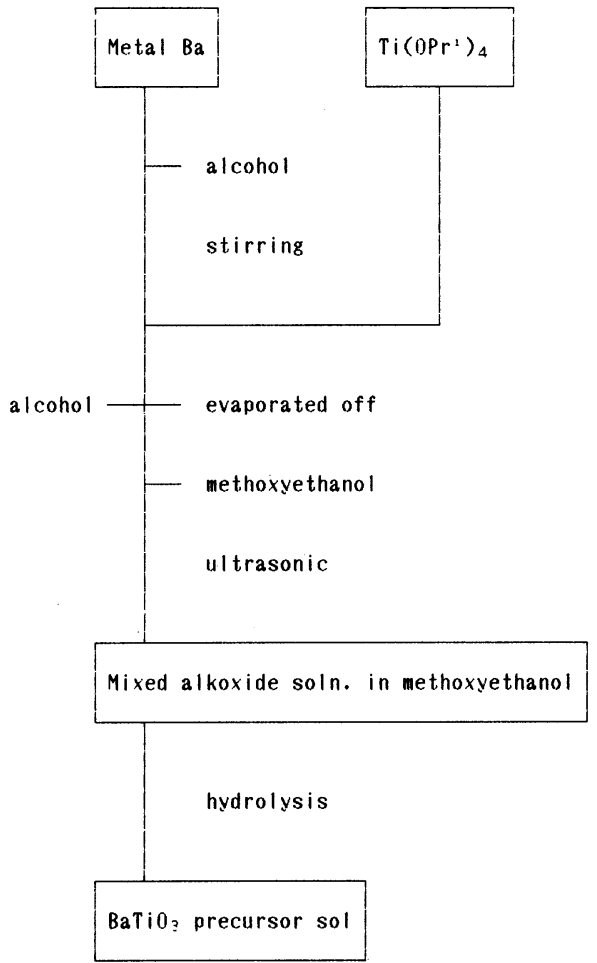

Fig. 1. The flowsheet for synthesis of $\mathrm{BaTiO}_{3}$ precursor sol.

（3）水/メトキシエタノール（75 $\mathrm{vol} \%)$

(4) 水/メトキシエタノール (66 vol \%)

（5）水/メトキシエタノール (50 vol \%)

（6）水/メトキシエタノール $(33 \mathrm{vol} \%)$

混合アルコキシド溶液をマグネチックスターラでかく はんしながら，（1)（６）の各希釈度の水を, 量を変 えて加え, チタン酸バリウム前駆体ゾルを合成した。加 水分解は特にことわらないかぎり室温で行った，実験操 作のフローシートを図 1 に示す.

\section{2 ゾルの粘度測定及びゾル粒子の分析}

合成したゾルの粘度変化はリオン製ビスコテスター VT 04 (中粘度用 1 号ロータ一使用）を用いて測定した。 測定は液温 $25^{\circ} \mathrm{C}$ で 30 分間行った.

ゾル粒子の分析は，合成したゾルを $70^{\circ} \mathrm{C}$ で 24 時間 乾燥させた粉末試料のほか, 更に各温度で 2 時間仮焼し たものを用意した. それらの粉末試料に対して粉末 X 線回折分析, エネルギー分散型分光分析を行い，更に電 子顕微鏡観察を行った.

粉末 X 線回折分析に用いた機器は理学電機製 RAD-1 $\mathrm{A}$ 型で測定条件は $\mathrm{Cu} K \boldsymbol{\alpha}$ 線（モノクロメータ一使用）, 管電圧 $40 \mathrm{kV}$ ，管電流 $20 \mathrm{~mA}$ で行った.

電子顕微鏡及びエネルギー分散型分光分析は日本電子 製 JEM-100 CXII 及び Kevex 製検出器モデル 3200-0019 亡エネルギー分散型分光分析装置 7077 QJ を組み合わ
せて使用した．電子顕微鏡用の試料は試料粉末を超音波 を用いて水によく分散させ，白金耳を用いて応研商事製

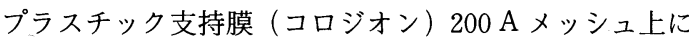
のせ，乾燥後観察及び分析を行った。

\section{3. 結果及び考察}

\section{1 加水分解における水の希釈度及び水量の影響}

合成したバリウムーチタニウム混合アルコキシド溶液 は，水の濃度が $66 \mathrm{vol} \%$ 以上のメトキシエタノール溶 液で加水分解したときには，加えた水量にかかわらず加 水操作と同時に水とアルコキシドの接触部で部分的なゲ ル化を生じて不均一なものとなった．また，部分ゲル化 の程度は水濃度が高いほど大きいことが観察された。

これは，水濃度が高すぎるためアルコキシドと水の反 応が急速に進行することによる．それに対して水濃度が $50 \mathrm{vol} \%, 33 \mathrm{vol} \%$ のメトキシエ夕ノール溶液で加水 分解した場合は部分的なゲル化は生じなかった．すなわ ち，均一なチタン酸バリウム前駆体ゾルを調製するため には加水分解のときの水濃度を $50 \mathrm{vol} \%$ 以下に抑える 必要がある.

図 2 にチタン酸バリウム換算で $3.2 \times 10^{-4} \mathrm{~mol} / \mathrm{ml}$ の 溶液 $120 \mathrm{ml}$ に対して $50 \mathrm{vol} \%$ 水一メトキシエタノール 混合溶液を $45,50,55,60 \mathrm{ml}$ 加えたときの $25^{\circ} \mathrm{C}$ での 粘度変化を示す.縦軸は粘度で横軸は時間を示している. いずれの場合も，加水後 10 秒間はマグネチックスター ラで混合を行った。

加えた水は

$$
\mathrm{Ba}(\mathrm{OR})_{2}+\mathrm{Ti}(\mathrm{OR})_{4}+3 \mathrm{H}_{2} \mathrm{O} \rightarrow \mathrm{BaTiO}_{3}+6 \mathrm{ROH}
$$
という反応を仮定した場合の化学量論量の各々 9.7 , $10.9 ， 12.1 ， 13.3 ， 14.5$ 倍に相当している. 加えた液 量が $45 \mathrm{ml}$ 以上の場合, 加えてから 30 分間内に粘度の 増加がみられたが， $40 \mathrm{ml}$ のときは測定時間とした 30 分間内に粘度の増加は確認できなかった。

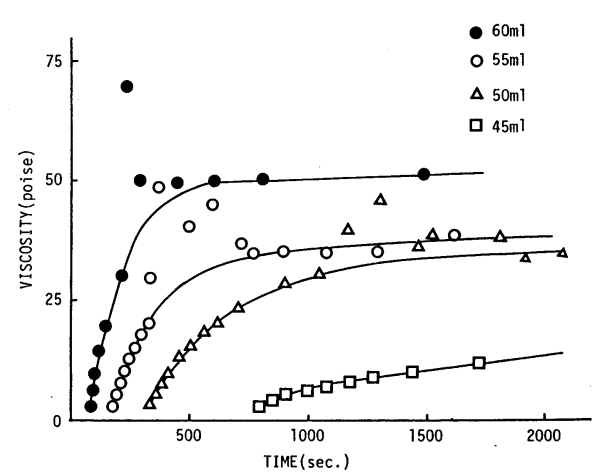

Fig. 2. Viscosity variation of $\mathrm{BaTiO}_{3}$ precursor sol with time. To $120 \mathrm{ml}$ of $\mathrm{Ba}$-Ti mixed alkoxide $(3.2 \times$ $\left.10^{-4} \mathrm{~mol} / \mathrm{ml}\right) 45,50,55$ and $60 \mathrm{ml}$ of water/methoxyethanol (50 vol \%) were added. 
図 2 から分かるように，加水量の増加に伴い急激な粘 度の増大が観察されるまでの時間が短縮され, 粘度変化 率も大きくなり,また最終粘度も高くなることが分かる. また，いずれの場合もゾルの粘度が約 30 poise 以上に 高まると測定值が著しく不安定となり，データにばらつ きがみられた。これはゾルの弾性が影響しているものと 思われる.

\section{2 アルコキシ基の影稫}

先に述べたように本実験でバリウムアルコキシドの合 成に用いたアルコールはメタノール，エタノール，イソ プロピルアルコールの 3 種類としたが, દ゙のアルコール を使用した場合においても 3.1 節で示したような結果と なり，アルコキシ基の違いによる認められる差は生じな かった。

\section{3 ゾル化条件に及ぼす成分元素の影響}

チタン酸バリウムの 4 価の成分であるチタニウムをジ ルコニウムに置換させたジルコン酸バリウムと, 2 価の 成分であるバリウムをストロンチウムに置換させたチ夕 ン酸ストロンチウム及び 2 価，4 価成分共に各々ストロ ンチウム, ジルコニウムに置換させたジルコン酸ストロ ンチウムについても同様な実験を行い成分元素の影響を 調べた。

各アルコキシド溶液の調製は図 1 に準じた. バリウ ムージルコニウム混合アルコキシドの調製はチタニウム テトライソプロポキシドの代わりにジルコニウムノルマ ルプロポキシド (Alfa Products 製) を用い，ストロン チウムーチタニウム混合アルコキシドの調製には金属バ リウムの代わりに金属ストロンチウムを用いた．各々に 対して濃度の異なる水-メトキシエタノールを, 量を変 えて加え, ゾル化の様子を観察した.

4 価成分がジルコニウムに置換されたバリウムージル コニウム系及びストロンチウムージルコニウム系では部 分ゲル化を起こさない水濃度が $50 \mathrm{vol} \%$ から $66 \mathrm{vol} \%$ に増加した. それに比較して 2 価成分のバリウムをスト ロンチウムに置換したストロンチウムーチタニウム系で は部分ゲル化を起こさない水濃度はバリウムーチタニウ ム系亡変わらなかった. 更にバリウムージルコニウム系, ストロンチウム-チタニウム系, ストロンチウム-ジルコ ニウム系共に 3.2 節で示した結果と同様にアルコキシ 基の影響は認められなかった.

すなわち,チタニウムとジルコニウムの置換において, 部分ゲル化を起こす水濃度に若干の差が見られたが，そ れ以外の成分元素の置換による大きな変化は見られな かった.

\section{4 ゾル化の限界濃度}

一般に調製されるゾルは乾燥収縮や焼成収縮を少なく するため, 高固体濃度であることが望まれる．ここでは 種々の濃度のアルコキシド溶液を調製し加水分解した.
その結果を表 1 に示す.

表より分かるように，チタン酸バリウム換算で約 $7 \times$ $10^{-4} \mathrm{~mol} / \mathrm{ml}$ という高濃度のチタン酸バリウム前駆体ゾ ルを合成することが可能であることが分かった.

\section{5 ゾル粒子の加熱変化}

図 3 にチタン酸バリウム前駆体ゾルを各温度で仮焼し たものの X 線回折パターンを示す．図から分かるよう に $70^{\circ} \mathrm{C}, 400^{\circ} \mathrm{C}$ では非晶質で, $600^{\circ} \mathrm{C}$ から結晶性チ夕 ン酸バリウムとなり, $800^{\circ}, 1000^{\circ} \mathrm{C}$ と仮焼温度が高く なるにつれてピークが鋭くなり結晶化が進行しているこ とが分かった．図4 にはチタン酸ストロンチウム前駆体 ゾル，図 5 にはジルコン酸バリウム前駆体ゾル，図6に

Table 1. The results for hydrolysis of various concentration $\mathrm{Ba}-\mathrm{Ti}$ mixed alkoxide solution.

\begin{tabular}{|c|c|c|c|l|}
\hline $\begin{array}{c}\text { Starting alkoxide } \\
\left(\text { as BaTi } 0_{2}\right)(m o l)\end{array}$ & $\begin{array}{l}\text { Amount of } \\
\text { solvent }(m)\end{array}$ & \multicolumn{2}{|c|}{$\begin{array}{l}\text { Water-Methoxyethanol } \\
(m 1)\end{array}$} & $\begin{array}{l}\text { condition after } \\
\text { hydrolysis }\end{array}$ \\
\hline \multirow{3}{*}{$3.6 \times 10^{-2}$} & 5 & 2 & 10 & partial gelation \\
\cline { 2 - 5 } & 5 & 2 & 15 & partial gelation \\
\cline { 2 - 5 } & 15 & 4 & 15 & partial gelation \\
\cline { 2 - 5 } & 20 & 4 & 15 & partial gelation \\
\cline { 2 - 5 } & 25 & 4 & 25 & solation \\
\cline { 2 - 5 } & 25 & 20 & solation \\
\hline
\end{tabular}

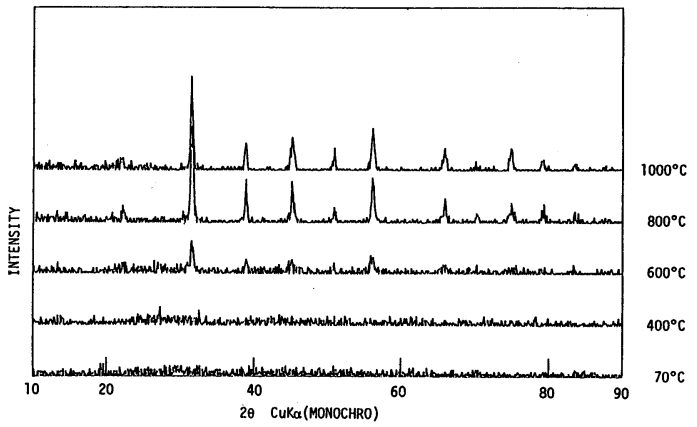

Fig. 3. X-ray diffraction patterns of $\mathrm{BaTiO}_{3}$ precursor sol calcined at various temperature.

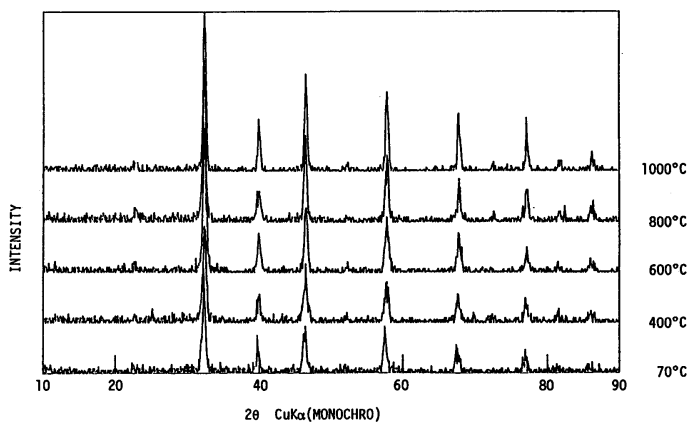

Fig. 4. X-ray diffraction patterns of $\mathrm{SrTiO}_{3}$ precursor sol calcined at various temperature. 


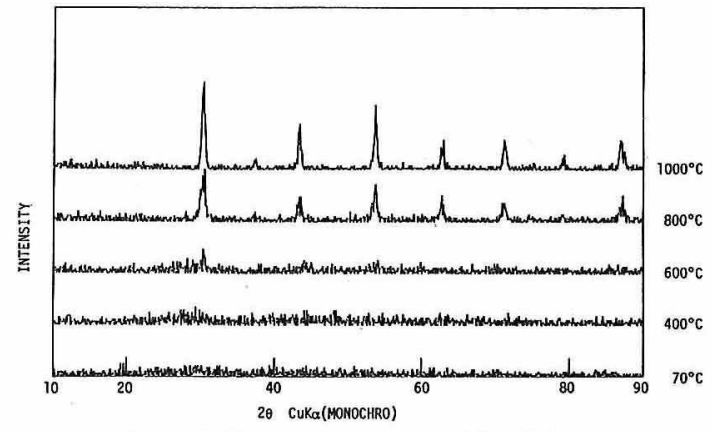

Fig. 5. X-ray diffraction patterns of $\mathrm{BaZrO}_{3}$ precursor sol calcined at various temperature.

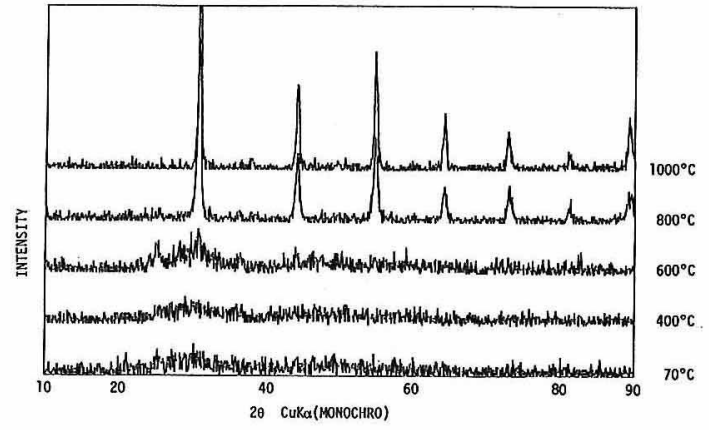

Fig. 6. X-ray diffraction patterns of $\mathrm{SrZrO}_{3}$ precursor sol calcined at various temperature.
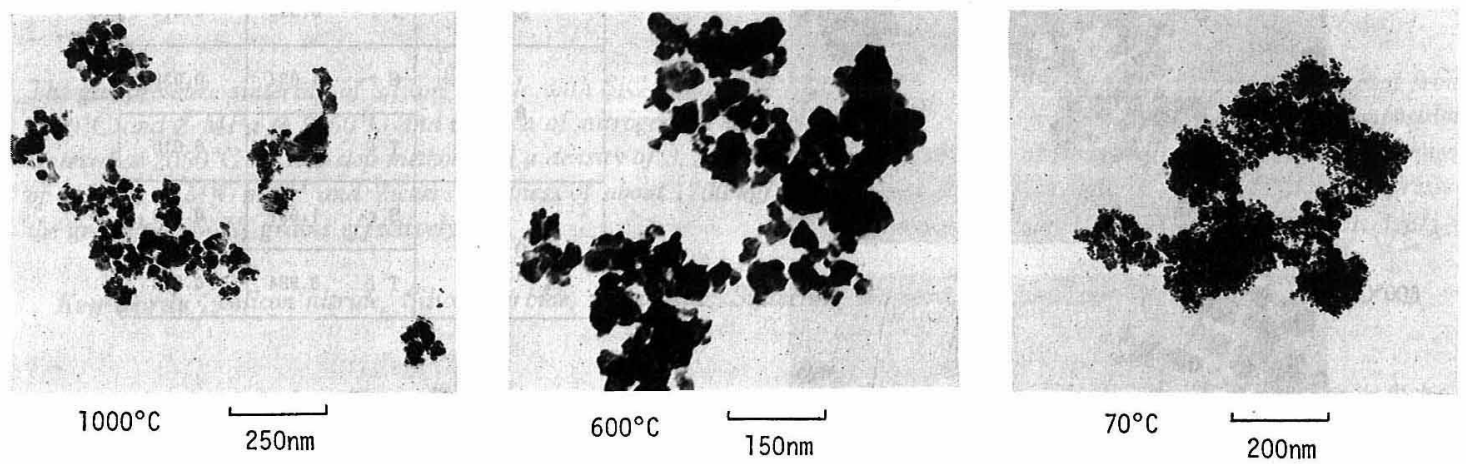

Fig. 7. Transmission electron micrographs of $\mathrm{BaTiO}_{3}$.

はジルコン酸ストロンチウム前駆体ゾルを各温度で仮焼 したものの X 線回折パターンを示す. チタン酸ストロ ンチウムは $70^{\circ} \mathrm{C}$ から結晶化している. ジルコン酸バリ ウムは $600^{\circ} \mathrm{C}$ 仮焼においてもわずかにピークが確認さ れる程度であり, $800^{\circ} \mathrm{C}$ 仮焼で結晶化した. ジルコン酸 ストロンチウムは $70^{\circ} \mathrm{C}$ から第 1 ピーク付近にブロード なピークが見られるが，やはり $800^{\circ} \mathrm{C}$ 以上の仮焼によっ てのみ結晶性ジルコン酸ストロンチウムが得られた。

図 7 にチタン酸バリウム前駆体ゾルを $70^{\circ}, 600^{\circ}$, $1000^{\circ} \mathrm{C}$ で乾燥及び仮焼したものの透過型電子顕微鏡写 真を示す. 図 7 から粒子径は $70^{\circ} \mathrm{C}$ では約 $10 \mathrm{~nm}$, $600^{\circ} \mathrm{C}$ では約 $40 \mathrm{~nm}, 1000^{\circ} \mathrm{C}$ では約 $60 \mathrm{~nm}$ であった.

\section{6 前駆体ゾルの組成均一性}

チタン酸バリウム前駆体ゾル粒子の化学的均一性を調 ベるためエネルギー分散型分光分析を用いて 10 点の点 分析を行った. ただし，本実験に用いた装置の分解能は $155 \mathrm{eV}$ であり，バリウムの $L \alpha$ 線 $(4.47 \mathrm{keV})$ とチ夕 ニウムの $K \alpha$ 線 $(4.51 \mathrm{keV})$ のピークが重なり, 分離が 困難なため, 分析にはチタン酸ストロンチウム前駆体ゾ ルを用いた. 分析結果を表 2 に, 粒子写真を図 8 に示す.

図から分かるようにン゙ル粒子は Sr：Ti の比が約 $1: 1$ で均一な化学組成を持っていることが分かる. 仮焼温度 が高くなるにつれて組成のばらつきがわずかに大きく

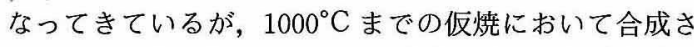
れたチタン酸ストロンチウムは非常に均一な組成を持っ ていることが分かる. 製法の過程より考え, 他の前駆体 ゾルについても同様な組成的均一性を持っていると予想 される.

\section{4. 総 括}

（1）バリウム-チタニウム系混合アルコキシドのメ トキシエタノール溶液を制限した条件で加水分解するこ とによってチタン酸バリウム前駆体ゾルを調製すること ができた．また，バリウムージルコニウム系，ストロン チウムーチタニウム系，ストロンチウムージルコニウム系 混合アルコキシドも各々制限した条件で加水分解するこ とによってジルコン酸バリウム前駆体ゾル, チタン酸ス トロンチウム前駆体ゾル，ジルコン酸ストロンチウム前 駆体ゾルを調製することができた。

加水分解条件は

(a) バリウム-チタニウム系，ストロンチウムーチ タニウム系においては, $3.6 \times 10^{-4} \mathrm{~mol} / \mathrm{ml}$ 濃度のア ルコキシド溶液に対して水濃度 $50 \mathrm{vol} \%$ 以下の水-メ トキシエタノール混合溶液を室温下で加える，

（b ）バリウムージルコニウム系，ストロンチウムジルコニウム系に対しては, $3.6 \times 10^{-4} \mathrm{~mol} / \mathrm{ml}$ 濃度 
$1000^{\circ} \mathrm{C}$

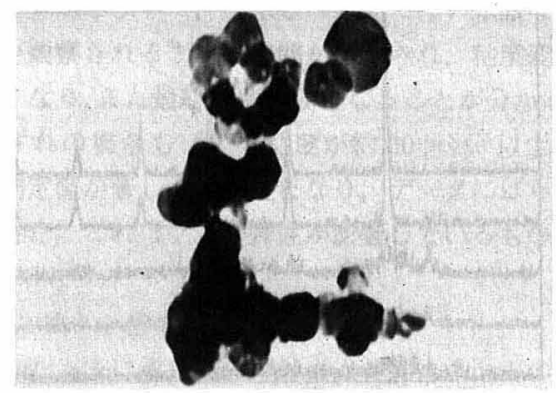

$800^{\circ} \mathrm{C}$

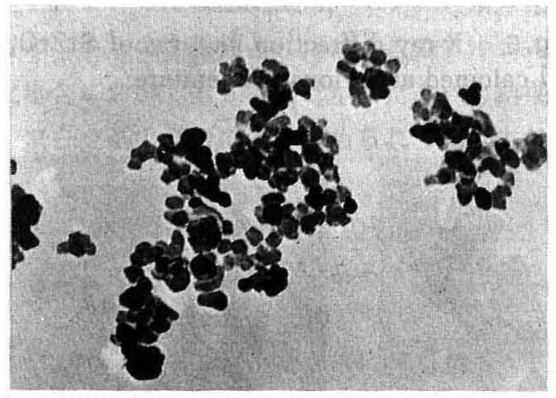

$600^{\circ} \mathrm{C}$

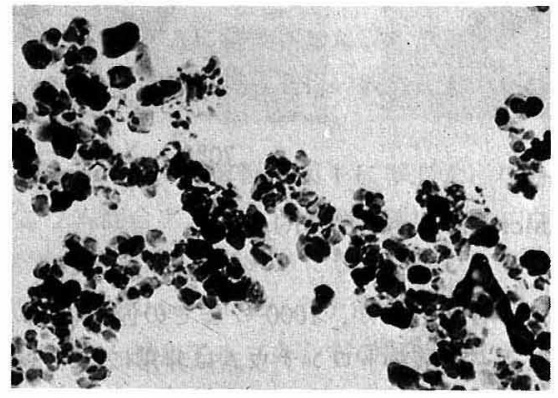

$400^{\circ} \mathrm{C}$

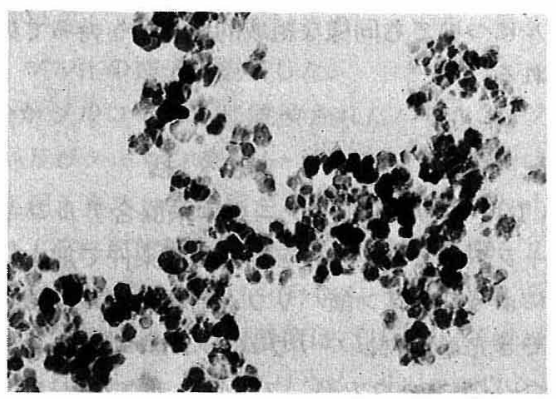

$70^{\circ} \mathrm{C}$

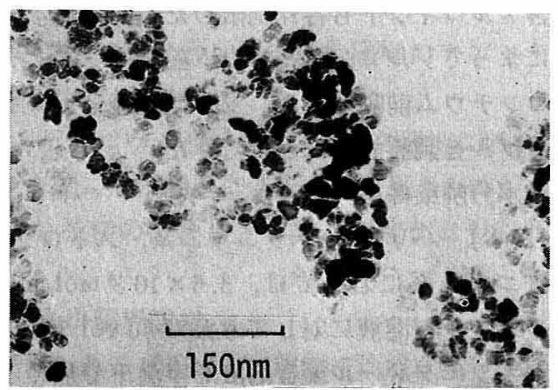

Fig. 8. Transmission electron micrographs of $\mathrm{SrTiO}_{3}$.
Table 2. Result of EDX analysis for $\mathrm{SrTiO}_{3}$ precursor sol calcined at various temperature.

\begin{tabular}{|c|c|c|c|}
\hline $\begin{array}{l}\text { calcination } \\
\text { temperatur ( }\left({ }^{\circ}\right)\end{array}$ & & $\begin{array}{l}\text { rage } \\
\text { ratio }\end{array}$ & $\begin{array}{l}\text { standerd } \\
\text { deviation }\end{array}$ \\
\hline \multirow{2}{*}{70} & $S \mathbf{r}$ & 1.067 & 0.026 \\
\hline & $\mathrm{T}$ i & 0.367 & 0.013 \\
\hline \multirow{2}{*}{400} & $\mathrm{~S} \mathrm{r}$ & 1.047 & 0.026 \\
\hline & $\mathrm{T} \mathrm{i}$ & 0.977 & 0.013 \\
\hline \multirow{2}{*}{600} & S r & 1.023 & 0.028 \\
\hline & $\mathrm{T}$ i & 0.989 & 0.014 \\
\hline \multirow{2}{*}{800} & $\mathrm{Sr}$ & 1.037 & 0.039 \\
\hline & $\mathrm{T} \mathrm{i}$ & 0.981 & 0.019 \\
\hline \multirow{2}{*}{1000} & $\mathrm{Sr}$ & 1.031 & 0.039 \\
\hline & $T i$ & 0.984 & 0.019 \\
\hline
\end{tabular}

のアルコキシド溶液に対して水濃度 $66 \mathrm{vol} \%$ 以下の 水ーメトキシエタノール混合溶液を室温下で加える, である。

（2）得られた前駆体ゾルを乾燥及び仮焼したところ 次の結果を得た。

(a) バリウムーチタニウム系では $600^{\circ} \mathrm{C}$ 以上で結 晶性のチタン酸バリウムが得られた。

（b）ストロンチウムーチタニウム系では $70^{\circ} \mathrm{C}$ 乾燥 時から結晶性のチタン酸ストロンチウムが得られた。

(c) バリウム-ジルコニウム系では $800^{\circ} \mathrm{C}$ 以上で 結晶性のジルコン酸バリウムが得られた.

（d）ストロンチウムージルコニウム系では $800^{\circ} \mathrm{C}$ 以上で結晶性のジルコン酸ストロンチウムが得られた. (3) チタン酸ストロンチウムの EDX 分析によりゾ 儿乾燥粉末粒子は化学組成が均一であり, 仮焼によって もその均一性は影響を受けないことが分かった。製法の 過程より考え, 他の前駆体ゾルについても同様に組成は 均一であると予想される.

\section{文 献}

1）尾崎義治, 日本の科学と技術, Vol. 25, No. 227, 43-51 (1984).

2）室地戸雄幸，セラミックス，12，420-26 (1977).

3) K.S. Mazdiyasni, Am. Ceram. Soc. Bull., 63, 591 (1984).

4）尾崎義治, セラミックス, 21, 102-10 (1986).

5）尾崎義治, 化学亡工業, 39, 348-50 (1986).

6）中垣正幸, “表面状態とコロイド状態”, 東京化学同人 (1968) p. 26. 